\title{
Daily growth increment formation in otoliths of Pacific tarpon Megalops cyprinoides during metamorphosis
}

\author{
H. L. Chen, W. N. Tzeng* \\ Institute of Fisheries Science, College of Life Science, National Taiwan University, No. 1, Sec. 4, Roosevelt Rd, \\ Taipei, Taiwan 106, ROC
}

\begin{abstract}
The otolith microstructure of Pacific tarpon Megalops cyprinoides was examined to determine whether there were influences on the deposition of otolith daily growth increments (DGIs) during metamorphosis from leptocephalus to juvenile. Leptocephali collected in a Taiwanese estuary in August 2003 were fully grown and completed metamorphosis in approximately $10 \mathrm{~d}$ during rearing in environmental conditions similar to those in the wild. The metamorphic process was divided into Stages II and III based on temporal changes in external morphology, otolith growth rate, and $\mathrm{Sr} / \mathrm{Ca}$ ratio. The otolith increment width (OIW) was comparatively small for the leptocephalus (Stage I) before the experiment, increased rapidly at Stage II, and reached a maximum at the beginning of Stage III. In contrast, the otolith Sr/Ca ratio decreased sharply after Stage II. Metamorphosis was accompanied by a breakdown of Sr-rich sulfated glycosaminoglycans (GAGs) in the body, a change of body organization, body length shrinkage, and otolith rapid growth; growth increments in otoliths were deposited daily throughout. The metamorphic process of the Pacific tarpon leptocephalus is analogous to that of the anguillid eel, and the mechanism of otolith DGI deposition during metamorphosis may be similar.
\end{abstract}

KEY WORDS: Elopiformes - Pacific tarpon $\cdot$ Megalops cyprinoides $\cdot$ Leptocephalus $\cdot$ Morphology Metamorphosis · Otolith · Daily growth increments $\cdot \mathrm{Sr} / \mathrm{Ca}$ ratio

Resale or republication not permitted without written consent of the publisher

\section{INTRODUCTION}

The Pacific tarpon Megalops cyprinoides is a member of the superorder Elopomorpha and is widely distributed in the Indo-Pacific oceans. The superorder Elopomorpha includes Elopiformes, Anguilliformes, Albuliformes and Saccopharyngiformes (Tsukamoto \& Okiyama 1997, Pfeiler 1999, Obermiller \& Pfeiler 2003). They are characterized by a willow-leaf-shaped larva (leptocephalus) and drastic changes in morphology (such as total length, body shape, and position of internal organs) during metamorphosis (Robins 1989, Forey et al. 1996). The Pacific tarpon belongs to the Elopiformes and may spawn offshore, after which its leptocephali drift with tidal currents and metamorphose into juveniles in estuaries (Tzeng \& Yu 1986, Coates 1987). Fast-growing Pacific tarpon leptocephali arrive at the estuary earlier than slow-growing leptocephali (Tzeng et al. 1998), but little is known about the metamorphic process of the leptocephalus.

Since Pannella (1971) discovered daily growth increments (DGIs) in otoliths, they have been widely used to determine the age, in days, of fishes (Campana \& Neilson 1985, Jones 1986). The DGI is a bipartite structure that includes an L-zone (mineral-rich layers) and a D-zone (organic-matrix-rich layers) (Kalish et al. 1995) that are deposited in a circadian rhythm, approximately every $24 \mathrm{~h}$ (Tanaka et al. 1981, Campana \& Neilson 1985, Tzeng \& Yu 1988, Beckman \& Wilson 1995). It is believed that otolith DGIs and the chemicals deposited with the increments will not be remodeled. Thus, we can reconstruct the daily life history of fish from their otoliths. However, the deposition rate of otolith DGIs may not be similar in all fishes because it 
is influenced by photoperiod, ontogenetic development, metamorphosis and feeding regime (Campana \& Neilson 1985, Rice et al. 1985, Jones 1986, Morales-Nin 2000). Any change in these factors may influence the otolith deposition rate. Therefore, the periodicity of the presumed DGIs should be validated before using them to determine the age of fish and to study their life history events (Beamish \& McFarlane 1983).

In most of the elopomorph fishes the presence of DGIs in the otoliths of leptocephalus during metamorphosis has not yet been validated. Dramatic changes in otolith increment width (OIW) and microchemistry during metamorphosis from leptocephalus to glass eel have been observed in the otoliths of conger eels (Lee \& Byun 1996) and of anguillid eels (Otake et al. 1994, 1997, Arai et al. 1997, 1999, 2002, Wang \& Tzeng 2000, Marui et al. 2001, Correia et al. 2003). Accordingly, Cieri \& McCleave (2000) speculated that DGIs might not be deposited continuously in the eels because the leptocephalus remodels its body organization during metamorphosis, which may influence otolith microstructure and the subsequent deposition rate of the DGIs. The present study used the Pacific tarpon leptocephalus as a model to investigate the deposition rhythms of presumed DGIs in the otoliths of elopomorph leptocephali during metamorphosis.

\section{MATERIALS AND METHODS}

Experimental design. Leptocephali of Pacific tarpon Megalops cyprinoides were collected on 1 August 2003 using a net set against the tidal current in the estuary of Gong-shy-tyan Creek, a tributary of the Tanshui river, Taiwan. Healthy leptocephali were selected $(\mathrm{n}=$ 33) and immediately transported to the laboratory. The leptocephali were immersed in a tetracycline (TC) solution of concentration $350 \mathrm{mg} \mathrm{l}^{-1}$ for $24 \mathrm{~h}$ to mark the otoliths with a fluorescent band at the onset of the experiment (Day 1). After TC marking, the fish were reared for $16 \mathrm{~d}$ at $25^{\circ} \mathrm{C}, 15$ psu salinity, and photoperiod of 10:14 h light:dark, similar to the environment in the estuary when we sampled. The leptocephali were fed daily throughout the experiment with a fixed quantity of newly hatched brine shrimp nauplii (Artemia spp.). Every 2 d, 5 fish were randomly sacrificed to examine changes in their morphology, otolith microstructure and microchemistry. The sacrificing of fish every $2 \mathrm{~d}$ allowed us to understand the timing of stage transition during metamorphosis. The number of DGIs beyond the TC mark were counted and compared with the number of rearing days as in other validation studies (Campana \& Neilson 1982, Geffen 1987, 1992).

Following Smith (1980), the development of tarpon was classified into 3 stages: Stage I is the period of pre- metamorphic leptocephalus larva, Stage II is the period when the larva decreases markedly in body length and Stage III is the period when the larva increases in body length again and terminates with the beginning of the juvenile stage. The leptocephali collected in the estuary were fully grown Stage I larvae.

Measurement of morphology. Changes during metamorphosis in the proportions of the body, fin, gill, gas bladder and stomach were examined in fresh specimens by profile projector and dissecting microscope. The eye diameter (ED), body depth (BD, the greatest vertical body depth), head length (HL), predorsal length (PDL, distance from the tip of the snout to the base of the first dorsal ray) and preanal length (PAL, distance from the tip of the snout to the posterior margin of the anus) were measured and expressed as a ratio of total length (TL). The ratio in relation to TL was separated by Stage II and fitted with a regression line to determine when the TL decreased to a minimum during metamorphosis. Finally, the fish were fixed with $95 \%$ ethanol for later otolith analysis.

Otolith preparation and examination. The sagittal otoliths of Pacific tarpon were removed and mounted with epoxy resin (Epofix, Struers). Then the otolith was polished using a Metaserv grinder-polisher (Buehler) - equipped with various grit sandpapers, $0.05 \mu \mathrm{m}$ alumina slurry and polishing cloth - until the primordium was revealed.

Strontium ( $\mathrm{Sr}$ ) and calcium (Ca) concentrations were measured from the primordium to the otolith edge by an electron probe microanalyser (EPMA, JXA-8900R, JEOL) with an electron beam size of $5 \times 4 \mu^{2}$. The accelerating voltage and probe current of the beam condition were set at $15 \mathrm{keV}$ and $3 \mathrm{nA}$. Strontianite $\left(\left[\mathrm{Sr}_{0.95} \mathrm{Ca}_{0.05}\right] \mathrm{CO}_{3}\right)$ and aragonite $\left(\mathrm{CaCO}_{3}\right)$ were used as standards to calibrate the concentration of $\mathrm{Sr}$ and Ca in the otolith.

After EPMA analysis, the otoliths were repolished and etched with $\mathrm{HCl}(0.05 \mathrm{M})$ from $10 \mathrm{~s}$ to 1 min to enhance the contrast of DGIs under a transmitted light microscope. The DGIs and OIWs were counted and measured from the primordium to the TC mark and the otolith edge, along the maximum radius of the anteroposterior axis, with a transmitted light microscope at 400× magnification. The TC mark in the otolith was examined by a fluorescence microscope. Excitation wavelength of the incident ultraviolet light was limited by a band-pass filter ( 400 to $440 \mathrm{~nm}$ ) and a long-pass barrier filter (470 nm) (Tzeng \& Yu 1989). A subsample of otoliths was used to examine the microstructure of DGIs by scanning electron microscope (SEM, Hitachi S520). DGIs, identified using SEM and transmitted light microscope images, were compared to determine whether the counting of DGIs was influenced by different treatment. 
Data analysis. The number of DGIs deposited after the TC mark in the Pacific tarpon otolith was correlated with the number of rearing days after the fish was marked. Temporal changes in the increment width along the maximum growth axis of the otolith were also analyzed. Differences in the OIW and the $\mathrm{Sr} / \mathrm{Ca}$ ratio between development stages were tested by analysis of variance (ANOVA). Differences were ranked with Scheffe's S multiple-comparison test at a significance level of $\alpha=0.01$. The daily periodicity of the DGIs in the tarpon otoliths was validated by regressing the DGIs deposited after the TC mark on the corresponding rearing day. This regression was compared with the theoretical regression line (slope $=1.0$ ) by an analysis of covariance (ANCOVA).

\section{RESULTS}

\section{Changes of morphology during metamorphosis}

The leptocephali of the Pacific tarpon Megalops cyprinoides were fully grown Stage I larvae taken during recruitment to the estuary (Fig. 1a). The leptocephali had a compressed body and were transparent with few melanophores along the ventral abdomen. Some of the leptocephali had a small transparent gas bladder. In Stage II of the metamorphosis, the body size shrank and the position of the dorsal fins, anal fins and gas bladder began moving anteriorly. The development of the heart, gills, red blood cells and digestive tract was visually observable (Fig. 1b,c). In Stage III of the metamorphosis, no change in size was observed. However, the internal tissues and organs continued to develop, the stomach capacity increased and melanophores were concentrated in the dorsal, caudal, and anal fins. The abdomen became silvery and a gradual behavioral change occurred from surface floating to benthic swimming (Fig. 1d,e). At the juvenile stage, the TL and BD of the tarpon abruptly increased and body proportions were now constant and well developed (Fig. 1f).

\section{Changes of body length and otolith radius during metamorphosis}

The mean $( \pm \mathrm{SD})$ TL of the leptocephali collected in the estuary was $26.80 \pm 4.29 \mathrm{~mm}$. The mean TL of the leptocephali decreased to about $21.29 \pm 0.55$ to $23.33 \pm$ $2.60 \mathrm{~mm}$ during the transition from Stage II to III of metamorphosis on Days 4 to 6 of the experiment. The TL remained low, averaging $21.99 \pm 1.50 \mathrm{~mm}$ on Day 8 , and then increased to $26.54 \pm 0.87 \mathrm{~mm}$ by Day 10 and to $26.70 \pm 0.91 \mathrm{~mm}$ by Day 16 at the beginning of the juvenile stage. The change in TL during metamor- phosis from leptocephalus to juvenile was curvilinear $\left(y=0.06 x^{2}-0.72 x+25.37\right.$, where $y=$ TL and $x=$ days after the TC mark). The theoretically smallest length of the tarpon during metamorphosis was $23 \mathrm{~mm}$ at $6.54 \mathrm{~d}$ after the TC mark (Fig. 2a).
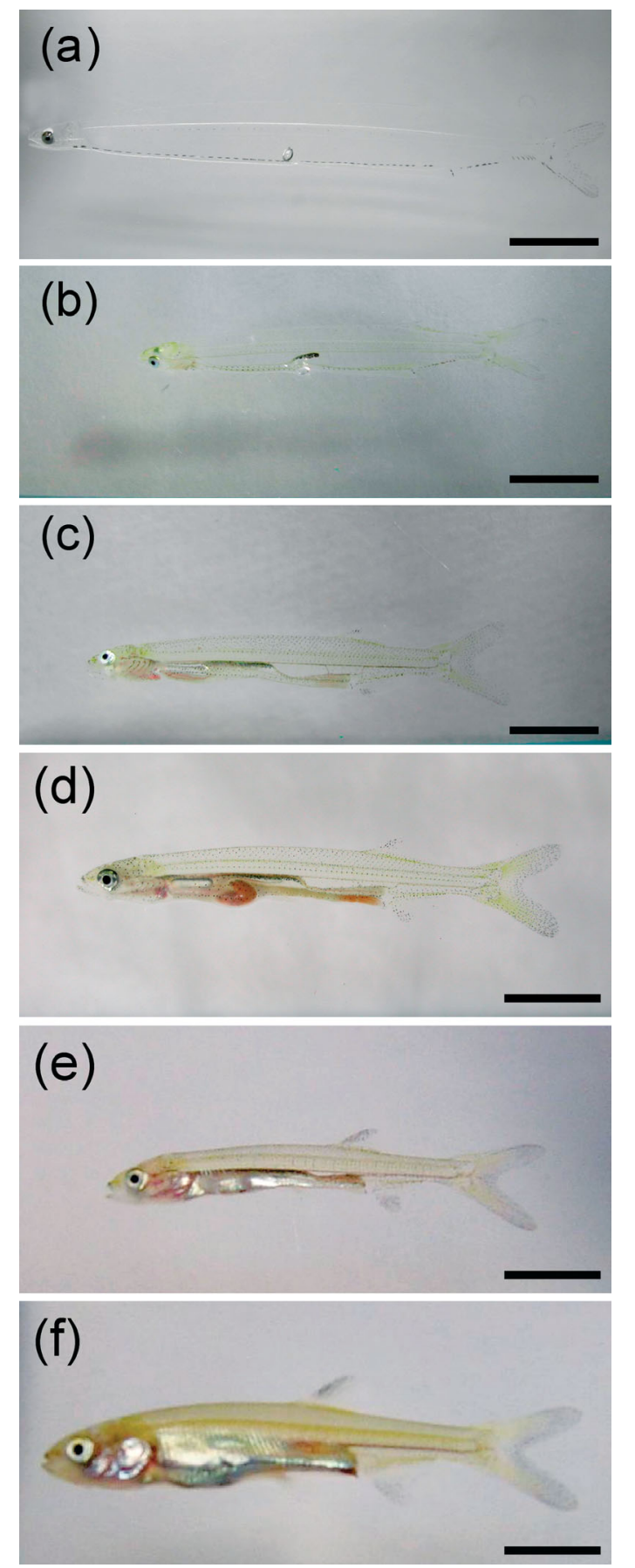

Fig. 1. Megalops cyprinoides. Changes in the external morphology during metamorphosis from leptocephalus to juvenile. (a) Fully grown leptocephalus at Stage I; $(b, c)$ metamorphosing leptocephalus (Stage II); (d,e) metamorphosing leptocephalus (Stage III); (f) juvenile. Scale bars $=5 \mathrm{~mm}$ 

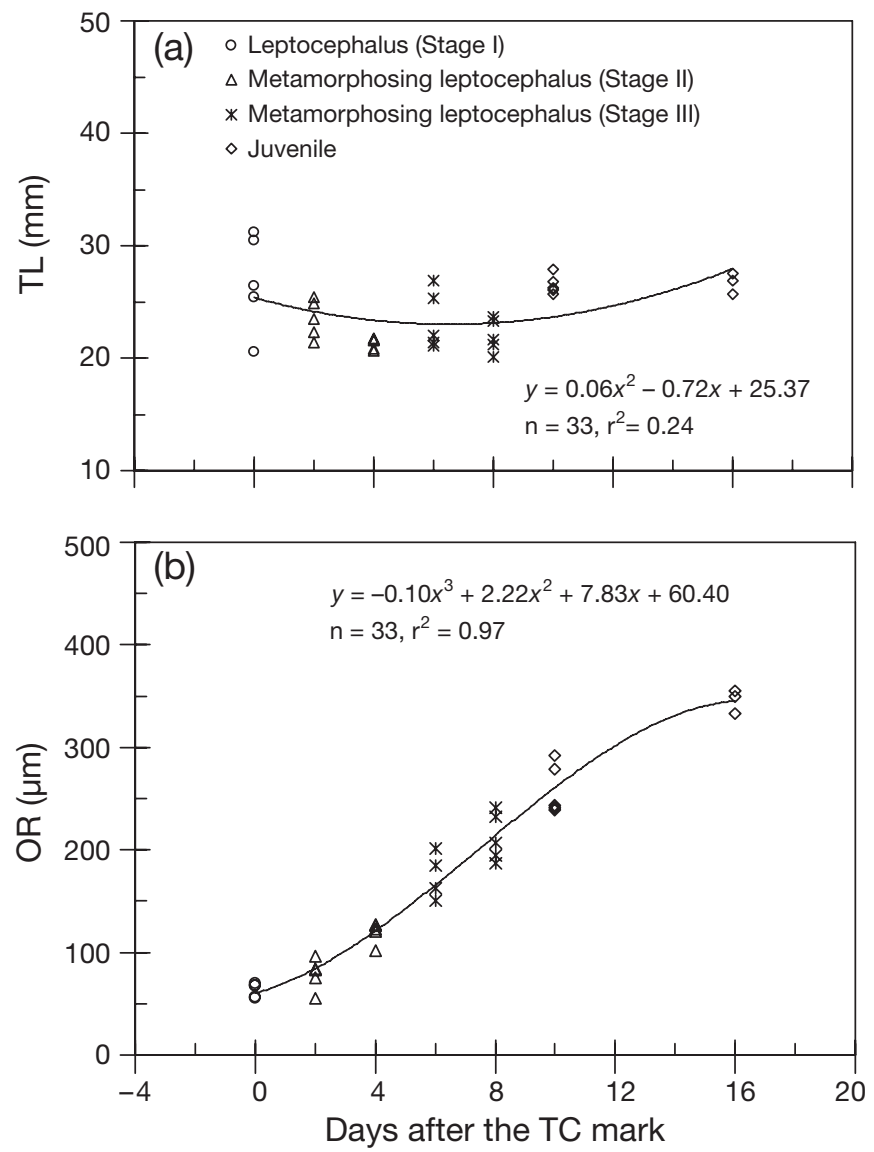

Fig. 2. Megalops cyprinoides. Changes in (a) total length (TL) and (b) otolith radius (OR) during metamorphosis from leptocephalus to juvenile

The otolith did not show negative growth during metamorphosis. The mean $( \pm \mathrm{SD})$ otolith radius $(\mathrm{OR})$ changed from $62.96 \pm 6.81 \mu \mathrm{m}$ in Stage I to 258.96 $\pm 24.57 \mu \mathrm{m}$ at the beginning of the juvenile stage. They significantly increased with number of rearing days $\left(y=-0.10 x^{3}+2.22 x^{2}+7.83 x+60.40\right.$, where $y=$ OR and $x=$ days after the TC mark) (Fig. 2b). The inflection point of the otolith growth rate curve was at $7.41 \mathrm{~d}$ after the TC mark, approximately $1 \mathrm{~d}$ after the fish decreased to its smallest size (Day 6.54). Although the somatic and otolith growth patterns differed, they all have inflection points during metamorphosis.

\section{Changes in body proportion with metamorphosis}

The regressions of body proportion on TL were divided into 2 groups according to whether TL decreased or increased with development during metamorphosis. Group 1 included fully grown leptocephali (Stage I) and Stage II larvae, whose TL decreased with development, and Group 2 included Stage III larvae and the juvenile stage, whose TL increased with development. Various body proportions changed with TL. In Group 1, the ratios PDL/TL and PAL/TL were significantly correlated with TL (Fig. 3), but ED/TL, BD/TL, HL/TL were negatively correlated with TL. In Group 2, PDL/TL, PAL/TL and HL/TL were significantly negatively correlated with $\mathrm{TL}$, and $\mathrm{BD}$, ED were not significantly correlated with TL. Thus, the relative growth rate of various body parts differed during metamorphosis. The dorsal fin and anus moved anteriorly, and the mean $( \pm \mathrm{SD})$ ratio of PDL/TL changed from $0.69 \pm$ 0.02 to $0.45 \pm 0.02$ and PAL/TL changed from $0.74 \pm$ 0.02 to $0.57 \pm 0.03$.

\section{Changes in OIW and the $\mathrm{Sr} / \mathrm{Ca}$ ratio during metamorphosis}

The otoliths of fully grown leptocephali (Stage I) were transparent and round, but the antero-posterior axis of the otolith grew faster during metamorphosis
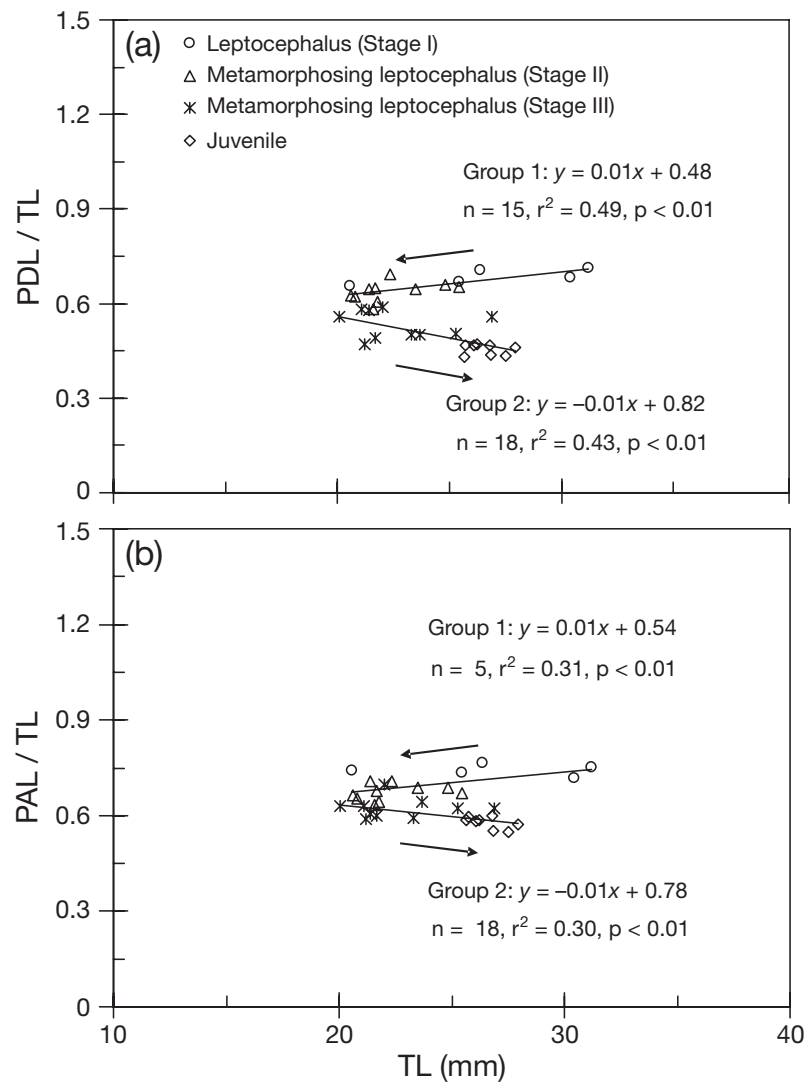

Fig. 3. Megalops cyprinoides. Linear regressions of body proportion on total length (TL) during metamorphosis. The regression lines were estimated by development stage, consisting of Group 1 (leptocephalus and Stage II) and Group 2 (Stage III and juvenile) according to the decrease or increase in the TL change, as indicated by arrows. (a) PDL/TL vs. TL; (b) PAL/TL vs. TL. (PDL: predorsal length; PAL: preanal length) 
(Stages II and III). The TC mark is not visible under normal light (Fig. 4a), but it shows clearly under fluorescent light (Fig. 4b). The microstructure of the otolith increment was similar when viewed by transmitted light microscope and SEM (Fig. 4a,c). Before the TC mark (zone A in Fig. 4d), the OIWs were small and consistent; after the TC mark they sharply increased and then gradually decreased towards the otolith edge (zone B in Fig. 4d). The otolith became thicker and appeared darker beyond the TC mark, which implies that organic materials were abundantly deposited during metamorphosis, especially - according to our observations - for well fed fish or those cultivated in high salinity water.

The mean $( \pm \mathrm{SD})$ OIW was back-calculated from the primordium to the otolith edge for each experiment day and classified by development stages (Fig. 5). The OIW at Stage I was narrow and relatively consistent, with an average of $2.81 \pm 1.10 \mu \mathrm{m}$. In Stage II the OIW was characterized by a sharp increase, averaging $13.57 \pm 5.27 \mu \mathrm{m}$. In Stage III the OIW increased to a maximum average of $23.32 \pm 4.04 \mu \mathrm{m}$ on Day 6 , and then decreased to a minimum of $14.55 \pm 5.80 \mu \mathrm{m}$ on Day 8 and $17.73 \pm 8.06$ on Day 10. The OIWs differed significantly among development stages of Pacific tarpon (ANOVA, p < 0.01).

The change in otolith mean $\mathrm{Sr} / \mathrm{Ca}$ ratio during metamorphosis was opposite to that for OIW (Fig. 6). The mean $( \pm \mathrm{SD})$ otolith $\mathrm{Sr} / \mathrm{Ca}$ ratio in the leptocephalus (Stage I) was $8.69 \pm 0.98$, ranging from $7.38 \pm 0.87$ to $9.50 \pm 0.67$. The $\mathrm{Sr} / \mathrm{Ca}$ ratio increased to a maximum of $9.53 \pm 1.27$ in the initial of Stage II (Spot 0), but decreased to $4.64 \pm 0.30$ in the late Stage II (Spot 4 or 5) and averaged $5.59 \pm 0.76$ in Stage III. Thus, the otolith $\mathrm{Sr} / \mathrm{Ca}$ ratios were higher in Stage I and decreased sharply at the beginning of metamorphosis.

\section{Validation of the DGI in Pacific tarpon otolith during metamorphosis}

The yellow fluorescent band of the TC mark was used as the starting point for the analysis of otolith DGI during rearing. The mean $( \pm \mathrm{SD})$ number of new incre-
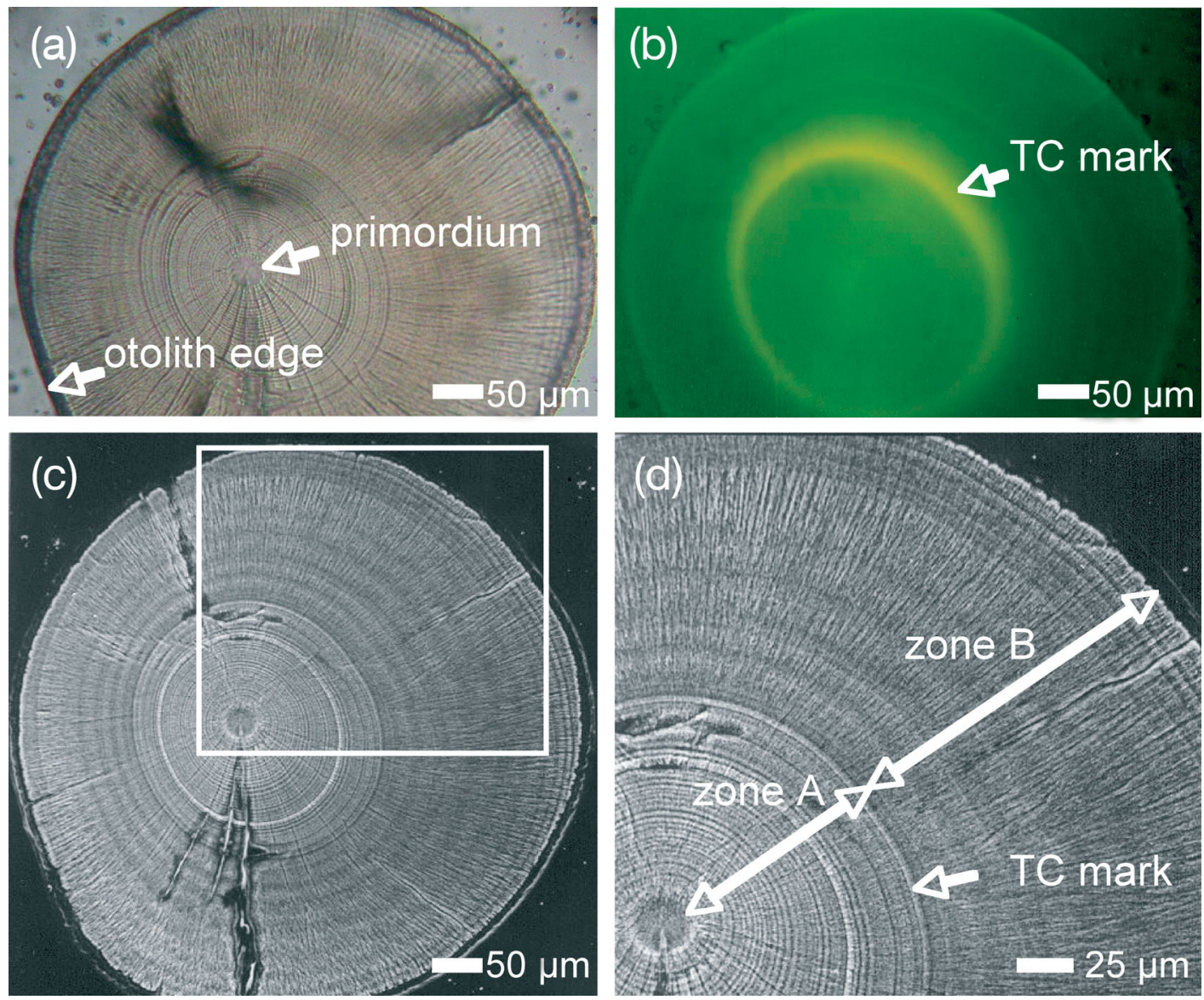

Fig. 4. Megalops cyprinoides. Daily growth increments in otoliths photographed with (a) transmitted and (b) fluorescent light microscopes, and (c,d) SEM. (d) Magnified from (c), zone A: leptocephalus stage, zone B: metamorphic stage 


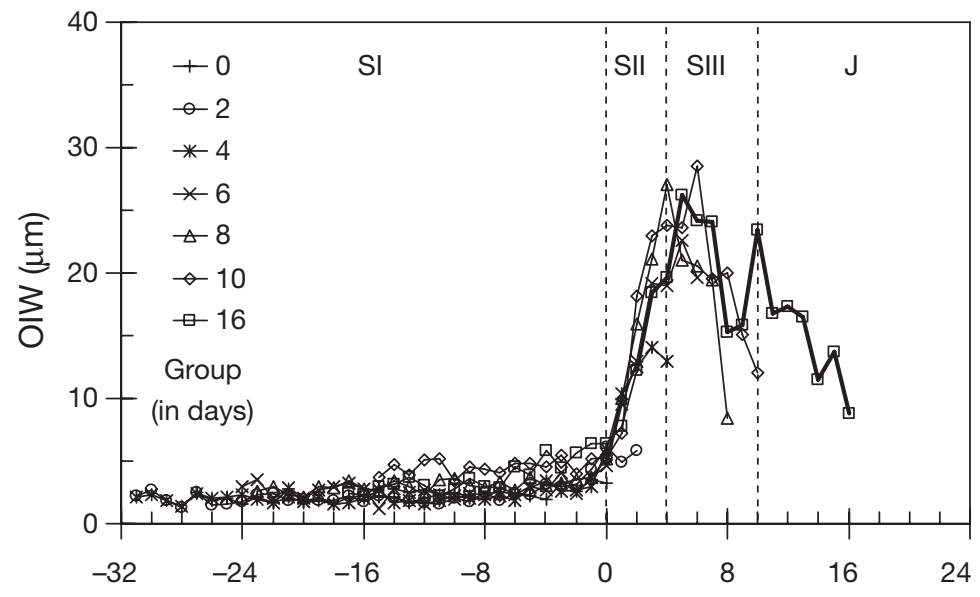

Days before and after the TC mark

Fig. 5. Megalops cyprinoides. Change in the mean otolith increment width (OIW) from the primordium to the edge sacrificed from Day 0 to Day 16 of the experiment. The TC mark was the onset of the experiment (Day 1). Sample size for each group is 5 except for Day 16 $(\mathrm{n}=3)$. (SI: Stage I; SII: Stage II; SIII: Stage III; J: Juvenile)

ments deposited after the TC mark were counted as $2 \pm 0.0,4.2 \pm 0.4,6.2 \pm 0.5,8 \pm 0.0,9.8 \pm 0.8$ and $16 \pm 1.0$, respectively in Days 2, 4, 6, 8, 10 and 16 of the experiment. The linear regression of new DGIs $(N)$ on rearing day $(D)$ was estimated to be $N=0.98 D+0.15$ (Fig. 7). The number of DGIs deposited after the TC mark was significantly correlated with the number of rearing days $(p<0.01)$ and the slope of the regression did not significantly differ from the 1:1 theoretical regression line with slope equaling 1 ( $p>0.05$ ). This validates the daily periodicity in the deposition of the DGI of Pacific tarpon during metamorphosis.

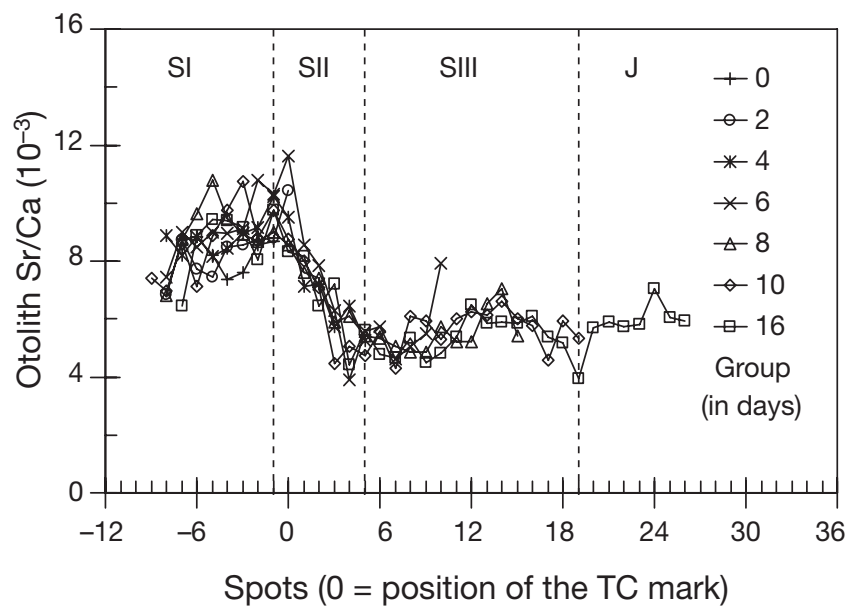

Fig. 6. Megalops cyprinoides. Changes in the mean otolith $\mathrm{Sr} / \mathrm{Ca}$ ratio from the primordium to the edge sacrificed from Day 0 to Day 16 of the experiment. The sample size for each group is 5, except for Day $16(\mathrm{n}=3)$. (SI: Stage I; SII: Stage II; SIII: Stage III; J: Juvenile)

\section{DISCUSSION}

\section{Are DGIs in otoliths regularly deposited during metamorphosis?}

Using of otolith to interpret early life history events is based on the underlying assumption that the otolith increment deposition rate is daily. Previous research postulated that the DGIs in leptocephalus otoliths were deposited daily, similar to those in the glass eel stage of anguillids, and were not affected by metamorphosis (Tsukamoto 1989). However, these hypotheses are difficult to validate because the artificial propagation of the Anguilla japonica leptocephalus has not yet been completely successful (Tanaka et al. 2001, Shinoda et al. 2004). On the other hand, the DGIs in otoliths during metamorphosis of the European eel A. anguilla were not clear and appeared as a diffuse zone (zone of uncountable increments), which may lead to an inaccurate estimate of age in days (Antunes \& Tesch 1997). Cieri \& McCleave (2000) suspected that the marginal portion of the otolith might be reabsorbed or that the DGIs were not deposited continuously during metamorphosis, which would lead to underestimates of the age of the American glass eel A. rostrata when back-calculated from the DGIs. However, our results for Pacific tarpon Megalops cyprinoides indicated that the number of otolith DGIs deposited after the TC mark was consistent with the number of rearing days (Fig. 7), which validated the daily periodicity of DGIs during metamorphosis. If the otolith of Pacific tarpon was reabsorbed as proposed for the American eel, its otolith radius and increment width should become smaller or decrease to zero over the rearing period, but

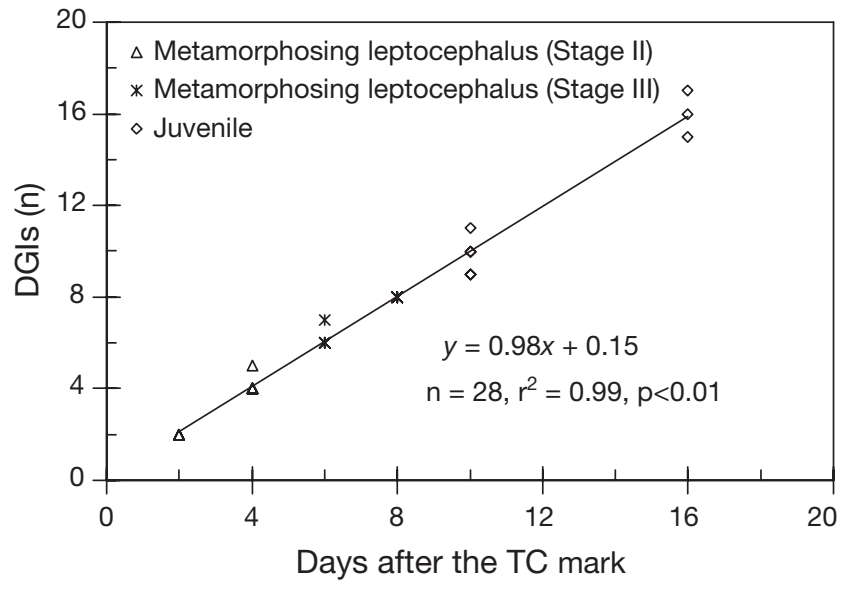

Fig. 7. Megalops cyprinoides. Relationship between the number of daily growth increments (DGIs) in otoliths and the rearing days after TC marking 
this did not occur and the growth of the otolith continued during metamorphosis. The otolith is metabolically inert and not subject to dissolution and reabsorption after deposition. Although otoliths may be dissolved at low $\mathrm{pH}$ when the fish is stressed (Mugiya \& Uchimura 1989), there is no evidence that otolith reabsorption will occur under normal conditions or that the $\mathrm{pH}$ in the endolymph declines during metamorphosis. Thus, the otolith reabsorption hypothesis is difficult to accept, at least for Pacific tarpon.

\section{Morphological and otolith microstructure changes during metamorphosis}

In most fish, TL has been used as a measure for both ontogeny and growth because it increases as they develop. However, Bell et al. (2003) suggested that TL measurements were not a useful indicator for the level of development in Elopomorpha since TL decreases at the beginning of metamorphosis. Indeed, our present study showed that the leptocephali of Pacific tarpon decreased in size and changed their body organization during metamorphosis, but that the variability in the relative growth indices PDL/TL and PAL/TL could be used to mark the ontogenetic progression of the morphological characteristics, as demonstrated for Conger oceanicus (Bell et al. 2003). PDL/TL and PAL/TL changed from 0.69 to 0.45 and from 0.74 to 0.57 , respectively, at the transition from Stage II to Stage III during metamorphosis, and were highly stage-specific. Thus the 2 indices are considered to be good indicators of ontogenetic transition of Pacific tarpon.

Zerbi et al. (2001) classified the otolith microstructure of Atlantic tarpon Megalops atlanticus into larval (mean OIW $1.3 \mu \mathrm{m}$ ) and juvenile zones (OIW range from 5 to $8 \mu \mathrm{m}$ ). However, this classification is too rough to express the relationship between otolith growth and ontogenetic development and does not clearly show the metamorphic stages. The mean OIW in the leptocephalus (Stage I) of Pacific tarpon was 2.2 to $2.3 \mu \mathrm{m}$ (Fig. $4 \mathrm{~d}$, zone A), and 5 to $13 \mu \mathrm{m}$ in metamorphic Stage II, but it decreased from 23 to $4 \mu \mathrm{m}$ in metamorphic Stage III (Fig. 4d, zone B). Accordingly, the stages classified by Zerbi et al. (2001) cannot provide sufficient information about the durations of the different developmental stages and the age at metamorphosis of Atlantic tarpon.

\section{Duration of metamorphosis}

Pfeiler (1984) noted that the metamorphosis of bonefish Albula sp. leptocephalus is relatively rapid and is typically completed in about $10 \mathrm{~d}$, which is similar to that for Pacific tarpon in this study (Fig. 1). He classified the short metamorphic period of bonefish leptocephali into 2 subphases (IIa and IIb) according to their hypoxia tolerance (Pfeiler 2001). The changes of OIW in Pacific tarpon during the ontogenetic transition from Stages II to III seem to coincide with the physiological changes in bonefish during the stage transition from phases IIa to IIb. In Stage II of Pacific tarpon leptocephalus or phase IIa of bonefish leptocephalus, a rapid body shrinkage and reduction in erythrocytes occurs, resulting in a low oxygen demand (Pfeiler 1999). During the metamorphic transition of the bonefish larva into a juvenile fish, the glycosaminoglycans (GAGs) are broken down, and function as storage polysaccharides, to support an endogenous source of energy in metabolism (Pfeiler et al. 2002). This possibly explains the rapid deposition of otolith increments in Pacific tarpon during metamorphosis. In addition, the increased OIW in Stage II indicated that there were large energy reserves to drive the early metamorphic process. The decreased OIW in late Stage III indicated that metamorphosis needed external food to reach the juvenile stage because we found that the starved larvae stopped development in early Stage III (authors' unpubl. data).

\section{Changes in otolith $\mathrm{Sr} / \mathrm{Ca}$ ratio during metamorphosis}

The duration of metamorphosis of the Anguilla eel leptocephalus has been estimated according to the temporal change in otolith OIW and $\mathrm{Sr} / \mathrm{Ca}$ ratio (Arai et al. 1997, 1999, 2002, Marui et al. 2001). These authors proposed that the leptocephali of Anguilla eels start metamorphosis as the otolith $\mathrm{Sr} / \mathrm{Ca}$ ratio begins sharply decreasing, and complete metamorphosis when the OIW reaches a maximum. However, our continuous observation on the metamorphosis of Pacific tarpon indicated that the peak OIW occurred at the beginning of Stage III, which was about 1 to $2 \mathrm{~d}$ after the $\mathrm{Sr} / \mathrm{Ca}$ ratio reached a minimum in Stage II, and that the metamorphic process was not yet completed at the peak OIW (Figs. $5 \& 6$ ). The peak OIW therefore seems an unsuitable indicator for defining the end of metamorphosis. The fall in the otolith $\mathrm{Sr} / \mathrm{Ca}$ ratio, on the other hand, occurred at the onset of leptocephalus metamorphosis. Falls in otolith $\mathrm{Sr} / \mathrm{Ca}$ ratios have been linked to reductions in ambient salinity experienced by various species of fish in certain environments (Secor \& Rooker 2000). The drastic decrease of Sr/Ca ratios in otoliths of Pacific tarpon during metamorphosis occurred regardless of whether the fish was in fresh water or seawater. Thus, the drastic change in otolith $\mathrm{Sr} / \mathrm{Ca}$ ratios during metamorphosis depends on 
internal physiological conditions more than external environmental conditions.

In conclusion, this study demonstrated that the DGIs in otoliths of the Pacific tarpon were regularly deposited irrespective of fish body changes and the drastic changes in otolith microstructure and microchemistry during metamorphosis. The leptocephalus of Pacific tarpon is a good model animal for studying the metamorphosis mechanism of elopomorph fishes. The developmental process of the leptocephalus was accurately recorded in the otolith and can be reconstructed from the otolith microstructure and Sr/Ca ratio. Additional ageing validation is needed for the premetamorphic leptocephalus, which would permit reliable prediction of the entire early life history of Pacific tarpon.

Acknowledgements. The National Science Council, Republic of China (NSC-92-2313-B-002-057) financially supported the study. We thank Dr. Y. Iizuka, Institute of Earth Sciences, Academia Sinica for his assistance in the EPMA operation, and Mr. Brian M. Jessop for reviewing the manuscript.

\section{LITERATURE CITED}

Antunes C, Tesh FW (1997) A critical consideration of the metamorphosis zone when identifying daily rings in otoliths of European eel, Anguilla anguilla (L.). Ecol Freshw Fish 6:102-107

Arai T, Otake T, Tsukamoto K (1997) Drastic changes in otolith microstructure and microchemistry accompanying the onset of metamorphosis in the Japanese eel Anguilla japonica. Mar Ecol Prog Ser 161:17-22

Arai T, Limbong D, Otake T, Tsukamoto K (1999) Metamorphosis and inshore migration of tropical eels Anguilla spp. in the Indo-Pacific. Mar Ecol Prog Ser 182:283-293

Arai T, Marui M, Miller MJ, Tsukamoto K (2002) Growth history and inshore migration of the tropical eel, Anguilla marmorata, in the Pacific. Mar Biol 140:309-316

Beamish RJ, McFarlane GA (1983) The forgotten requirement for age validation in fisheries biology. Trans Am Fish Soc 112:735-743

Beckman DW, Wilson CA (1995) Seasonal timing of opaque zone formation in fish otoliths. In: Secor DH, Dean JM, Campana SE (eds) Recent developments in fish otolith research. University of South Carolina Press, Columbia, $\mathrm{SC}, \mathrm{p} 27-43$

Bell GW, Witting DA, Able KW (2003) Aspects of metamorphosis and habitat use in the conger eel, Conger oceanicus. Copeia 3:544-552

Campana SE, Neilson JD (1982) Daily growth increments in otoliths of starry flounder (Platichthys stellatus) and the influence of some environmental variables in their production. Can J Fish Aquat Sci 39:937-942

Campana SE, Neilson JD (1985) Microstructure of fish otoliths. Can J Fish Aquat Sci 42:1014-1032

Cieri MD, McCleave JD (2000) Discrepancies between otoliths of larvae and juveniles of the American eel: Is something fishy happening at metamorphosis? J Fish Biol 57: 1189-1198

Coates D (1987) Observation on the biology of tarpon, Megalops cyprinoides (Broussonet) (Pisces: Megalopidae), in the Sepik River, northern Papua New Guinea. Aust J Mar Freshw Res 38:529-535

Correia AT, Antunes C, Isidro EJ, Coimbra J (2003) Changes in otolith microstructure and microchemistry during larval development of the European conger eel (Conger conger). Mar Biol 142:777-789

Forey PL, Littlewood DTJ, Ritchie P, Meyer A (1996) Interrelationships of elopomorph fishes. In: Stiassny MLJ, Parenti LR, Johnson GD (eds) Interrelationships of fishes. Academic Press, New York, p 175-191

Geffen AJ (1987) Methods of validating daily increment deposition in otoliths of larval fish. In: Summerfelt RC, Hall GE (eds) The age and growth of fish. Iowa State University Press, Ames, IA, p 223-240

Geffen AJ (1992) Validation of otolith increment deposition rate. In: Stevenson DK, Campana SE (eds) Otolith microstructure examination and analysis. Can Spec Publ Fish Aquat Sci 117, p 101-113

Jones C (1986) Determining age of larval fish with the otolith increment technique. Fish Bull 84:91-103

Kalish JM, Beamish RJ, Brothers EB, Casselman JM and 7 others (1995) Glossary for otolith studies. In: Secor DH, Dean JM, Campana SE (eds) Recent developments in fish otolith research. University of South Carolina Press, Columbia, SC, p 723-729

Lee TW, Byun JS (1996) Microstructural growth in otoliths of conger eel (Conger myriaster) leptocephali during the metamorphic stage. Mar Biol 125:259-268

Marui M, Arai T, Miller MJ, Jellyman DJ, Tsukamoto K (2001) Comparison of early life history between New Zealand temperate eels and Pacific tropical eels revealed by otolith microstructure and microchemistry. Mar Ecol Prog Ser 213:273-284

Morales-Nin B (2000) Review of the growth regulation processes of otolith daily increment formation. Fish Res 46: $53-67$

Mugiya Y, Uchimura T (1989) Otolith resorption induced by anaerobic stress in goldfish Carassius auratus. J Fish Biol 35:813-818

Obermiller LE, Pfeiler E (2003) Phylogenetic relationships of elopomorph fishes inferred from mitochondrial ribosomal DNA sequences. Mol Phylogenet Evol 26:202-214

Otake T, Ishii T, Nakahara M, Nakamura R (1994) Drastic changes in otolith strontium:calcium ratios in leptocephali and glass eels of Japanese eel Anguilla japonica. Mar Ecol Prog Ser 112:189-193

Otake T, Ishii T, Nakahara M, Nakamura R (1997) Changes in otolith strontium: calcium ratios in metamorphosing Conger myriaster leptocephali. Mar Biol 128:565-572

Pannella G (1971) Fish otoliths: daily growth layers and periodical patterns. Science 173:1124-1127

Pfeiler E (1984) Glycosaminoglycan breakdown during metamorphosis of larval bonefish Albula. Mar Biol Lett 5: 241-249

Pfeiler E (1999) Developmental physiology of elopomorph leptocephali. Comp Biochem Physiol A 123:113-128

Pfeiler E (2001) Changes in hypoxia tolerance during metamorphosis of bonefish (Albula sp.) leptocephali. J Fish Biol 59:1677-1681

Pfeiler E, Toyoda H, Williams MD, Nieman RA (2002) Identification, structural analysis and function of hyaluronan in developing fish larvae (leptocephali). Comp Biochem Physiol B 132:443-451

Rice JA, Crowder LB, Binkowski FP (1985) Evaluating the otolith increment analysis method for bloater Coregonus hoyi: Do otoliths ring true? Trans Am Fish Soc 114: $532-539$ 
Robins CR (1989) The phylogenetic relationships of the anguilliform fishes. In: Böhlke EB (ed) Fishes of the western North Atlantic. Part 9, Vol 1. Orders Anguilliformes and Saccopharyngiformes. Sears Foundation for Marine Research, New Haven, CT, p 9-23

Secor DH, Rooker JR (2000) Is otolith strontium a useful scalar of life-cycles in estuarine fishes? Fish Res 46:359-371

Shinoda A, Tanaka H, Kagawa H, Ohta H, Tsukamoto K (2004) Otolith microstructural analysis of reared larvae of the Japanese eel Anguilla japonica. Fish Sci 70:339-341

Smith DG (1980) Early larvae of the tarpon, Megalops atlantica Valenciennes (Pisces: Elopidae), with notes on spawning in the Gulf of Mexico and the Yucatan Channel. Bull Mar Sci 30:136-141

Tanaka K, Mugiya Y, Yamada J (1981) Effects of photoperiod and feeding on daily growth patterns in otoliths of juvenile Tilapia nicolica. Fish Bull 79:459-466

Tanaka H, Kagawa H, Ohta H (2001) Production of leptocephali of Japanese eel (Anguilla japonica) in captivity. Aquaculture 201:51-60

Tsukamoto K (1989) Otolith daily increments in the Japanese eel. Nippon Suisan Gakkaishi 55:1017-1021

Tsukamoto Y, Okiyama M (1997) Metamorphosis of the Pacific tarpon, Megalops cyprinoides (Elopiformes, Mega-

Editorial responsibility: Otto Kinne (Editor-in-Chief), Oldendorf/Luhe, Germany lopidae) with remarks on development patterns in the Elopomorpha. Bull Mar Sci 60:23-36

Tzeng WN, Yu SY (1986) Occurrence of the leptocephalus larvae of Elops hawaiensis and Megalops cyprinoides in the Gong-shy-tyan River estuary of north Taiwan with reference to some ecological and taxonomic aspects. In: Proceedings of the Symposium on Marine Biological Science, Biology Research Center. Nat Sci Council Monogr 14:165-176

Tzeng WN, Yu SY (1988) Daily growth increments in otoliths of milkfish, Chanos chanos (Forsskal), larvae. J Fish Biol 32:495-504

Tzeng WN, Yu SY (1989) Validation of daily growth increments in otoliths of milkfish larvae by oxytetracycline labeling. Trans Am Fish Soc 118:168-174

Tzeng WN, Wu CE, Wang YT (1998) Age of Pacific tarpon, Megalops cyprinoides, at estuarine arrival and growth during metamorphosis. Zool Stud 37:177-183

Wang $\mathrm{CH}$, Tzeng WN (2000) The timing of metamorphosis and growth rates of American and European eel leptocephali: a mechanism of larval segregative migration. Fish Res 46:191-205

Zerbi A, Aliaume C, Joyeux JC (2001) Growth of juvenile tarpon in Puerto Rican estuaries. J Mar Sci 58:87-95

Submitted: January 12, 2005; Accepted: September 26, 2005 Proofs received from author(s): March 17, 2006 